\title{
THE KNOWLEDGE-BASED ECONOMY: TRENDS AND IMPLICATIONS
}

\author{
Lect. univ. dr. Maria-Cristina STEFAN, crys07stefan@yahoo.com \\ Universitatea Valahia din Târgovişte \\ Facultatea de Ştiințe Economice \\ Ec. drd. Corneliu STEFAN \\ Consiliul Județean Dâmbovița
}

\begin{abstract}
The economies of the developed countries are increasingly based on knowledge and information. Knowledge is now recognised as the driver of productivity and economic growth, leading to a new focus on the role of information, technology and learning in economic performance. The term knowledge-based economy stems from this fuller recognition of the place of knowledge and technology in modern economies.

This analysis is increasingly directed to understanding the dynamics of the knowledge-based economy and its relationship to traditional economics, as reflected in new growth theory. The growing codification of knowledge and its transmission through communications and computer networks has led to the emerging information society.
\end{abstract}

The term knowledge-based economy results from a fuller recognition of the role of knowledge and technology in economic growth. Knowledge, as embodied in human beings (as human capital) and in technology, has always been central to economic development. But only over the last few years has its relative importance been recognised, just as that importance is growing.

Economists continue to search for the foundations of economic growth. Traditional production functions focus on labour, capital, materials and energy; knowledge and technology are external influences on production. Now analytical approaches are being developed so that knowledge can be included more directly in production functions. Investments in knowledge can increase the productive capacity of the other factors of production as well as transform them into new products and processes. And since these knowledge investments are characterised by increasing (rather than decreasing) returns, they are the key to long-term economic growth.

It is not a new idea that knowledge plays an important role in the economy. Adam Smith referred to new layers of specialists who are men of speculation and who make important contributions to the production of economically useful knowledge. Friedrich List emphasised the infrastructure and institutions which contribute to the development of productive forces through the creation and distribution of knowledge. The Schumpeterian idea of innovation as a major force of economic dynamics has been followed up by modern Schumpeterian scholars such as Galbraith, Goodwin and Hirschman. And economists such as Romer and Grossman are now developing new growth theories to explain the forces which drive long-term economic growth.

According to the neo-classical production function, returns diminish as more capital is added to the economy, an effect which may be offset, however, by the flow of new technology. Although technological progress is considered an engine of growth, there is no definition or explanation of technological processes. In new growth theory, knowledge can raise the returns on investment, which can in turn contribute to the accumulation of knowledge. It does this by 
stimulating more efficient methods of production organisation as well as new and improved products and services. There is thus the possibility of sustained increases in investment which can lead to continuous rises in a country's growth rate. Knowledge can also spill over from one firm or industry to another, with new ideas used repeatedly at little extra cost. Such spillovers can ease the constraints placed on growth by scarcity of capital.

Technological change raises the relative marginal productivity of capital through education and training of the labour force, investments in research and development and the creation of new managerial structures and work organisation. Analytical work on long-term economic growth shows that in the 20th century the factor of production growing most rapidly has been human capital, but there are no signs that this has reduced the rate of return to investment in education and training (Abramowitz, 1989). Investments in knowledge and capabilities are characterised by increasing (rather than decreasing) returns. These findings argue for modification of neo-classical equilibrium models - which were designed to deal with the production, exchange and use of commodities - in order to analyse the production, exchange and use of knowledge.

Incorporating knowledge into standard economic production functions is not an easy task, as this factor defies some fundamental economic principles, such as that of scarcity. Knowledge and information tend to be abundant; what is scarce is the capacity to use them in meaningful ways. Nor is knowledge easily transformed into the object of standard economic transactions. To buy knowledge and information is difficult because by definition information about the characteristics of what is sold is asymmetrically distributed between the seller and the buyer. Some kinds of knowledge can be easily reproduced and distributed at low cost to a broad set of users, which tends to undermine private ownership. Other kinds of knowledge cannot be transferred from one organisation to another or between individuals without establishing intricate linkages in terms of network and apprenticeship relationships or investing substantial resources in the codification and transformation into information.

In order to facilitate economic analysis, distinctions can be made between different kinds of knowledge which are important in the knowledge-based economy: know-what, know-why, know- how and know-who. Knowledge is a much broader concept than information, which is generally the "know-what" and "know-why" components of knowledge. These are also the types of knowledge which come closest to being market commodities or economic resources to be fitted into economic production functions. Other types of knowledge - particularly know-how and know-who - are more "tacit knowledge" and are more difficult to codify and measure (Lundvall and Johnson, 1994).

$>$ Know-what refers to knowledge about "facts". How many people live in New York? What are the ingredients in pancakes? And when was the battle of Waterloo? Are examples of this kind of knowledge. Here, knowledge is close to what is normally called information - it can be broken down into bits. In some complex areas, experts must have a lot of this kind of knowledge in order to fulfil their jobs. Practitioners of law and medicine belong to this category.

$>$ Know-why refers to scientific knowledge of the principles and laws of nature. This kind of knowledge underlies technological development and product and process advances in most industries. The production and reproduction of know-why is often organised in specialised organisations, such as research laboratories and universities. To get access to this kind of knowledge, firms have to interact with these organisations either through recruiting scientifically-trained labour or directly through contacts and joint activities. 
Know-how refers to skills or the capability to do something. Businessmen judging market . prospects for a new product or a personnel manager selecting and training staff have to use their know-how. The same is true for the skilled worker operating complicated machine tools. Know-how is typically a kind of knowledge developed and kept within the border of an individual firm. One of the most important reasons for the formation of industrial networks is the need for firms to be able to share and combine elements of know-how.

$>$ This is why know-who becomes increasingly important. Know-who involves information about who knows what and who knows how to do what. It involves the formation of special social relationships which make it possible to get access to experts and use their knowledge efficiently. It is significant in economies where skills are widely dispersed because of a highly developed division of labour among organisations and experts. For the modern manager and organisation, it is important to use this kind of knowledge in response to the acceleration in the rate of change. The know-who kind of knowledge is internal to the organisation to a higher degree than any other kind of knowledge.

Learning to master the four kinds of knowledge takes place through different channels. While know-what and know-why can be obtained through reading books, attending lectures and accessing databases, the other two kinds of knowledge are rooted primarily in practical experience. Know-how will typically be learned in situations where an apprentice follows a master and relies upon him as the authority. Know-who is learned in social practice and sometimes in specialised educational environments. It also develops in day-to-day dealings with customers, sub-contractors and independent institutes. One reason why firms engage in basic research is to acquire access to networks of academic experts crucial for their innovative capability. Know-who is socially embedded knowledge which cannot easily be transferred through formal channels of information.

The development of information technology may be regarded as a response to the need for handling the know-what and know-why portions of knowledge more effectively. Conversely, the existence of information technology and communications infrastructures gives a strong impetus to the process of codifying certain types of knowledge. All knowledge which can be codified and reduced to information can now be transmitted over long distances with very limited costs. It is the increasing codification of some elements of knowledge which have led the current era to be characterised as "the information society" - a society where a majority of workers will soon be producing, handling and distributing information or codified knowledge.

The digital revolution has intensified the move towards knowledge codification and altered the share of codified $v s$. tacit knowledge in the knowledge stock of the economy. Electronic networks now connect a vast array of public and private information sources, including digitised reference volumes, books, scientific journals, libraries of working papers, images, video clips, sound and voice recordings, graphical displays as well as electronic mail. These information resources, connected through various communications networks, represent the components of an emerging, universally accessible digital library.

Due to codification, knowledge is acquiring more of the properties of a commodity. Market transactions are facilitated by codification, and diffusion of knowledge is accelerated. In addition, codification is reducing the importance of additional investments to acquire further knowledge. It is creating bridges between fields and areas of competence and reducing the "dispersion" of knowledge.

These developments promise an acceleration of the rate of growth of stocks of accessible knowledge, with positive implications for economic growth. They also imply increased change in 
the knowledge stock due to higher rates of scrapping and obsolescence, which will put greater burdens on the economy's adjustment abilities. While information technologies are speeding up the codification of knowledge and stimulating growth in the knowledge-based economy, they have implications for the labour force.

While information technologies may be moving the border between tacit and codified knowledge, they are also increasing the importance of acquiring a range of skills or types of knowledge. In the emerging information society, a large and growing proportion of the labour force is engaged in handling information as opposed to more tangible factors of production. Computer literacy and access to network facilities tend to become more important than literacy in the traditional sense. Although the knowledge-based economy is affected by the increasing use of information technologies, it is not synonymous with the information society. The knowledgebased economy is characterised by the need for continuous learning of both codified information and the competencies to use this information.

As access to information becomes easier and less expensive, the skills and competencies relating to the selection and efficient use of information become more crucial. Tacit knowledge in the form of skills needed to handle codified knowledge is more important than ever in labour markets.

Codified knowledge might be considered as the material to be transformed, and tacit knowledge, particularly know-how, as the tool for handling this material. Capabilities for selecting relevant and disregarding irrelevant information, recognising patterns in information, interpreting and decoding information as well as learning new and forgetting old skills are in increasing demand.

The accumulation of tacit knowledge needed to derive maximum benefit from knowledge codified through information technologies can only be done through learning. Without investments oriented towards both codified and tacit skill development, informational constraints may be a significant factor degrading the allocative efficiency of market economies. Workers will require both formal education and the ability to acquire and apply new theoretical and analytical knowledge; they will increasingly be paid for their codified and tacit knowledge skills rather than for manual work.

Education will be the centre of the knowledge-based economy, and learning the tool of individual and organisational advancement. This process of learning is more than just acquiring formal education. In the knowledge-based economy learning-by-doing is paramount. A fundamental aspect of learning is the transformation of tacit into codified knowledge and the movement back to practice where new kinds of tacit knowledge are developed. Training and learning in non-formal settings, increasingly possible due to information technologies, are more common. Firms themselves face the need to become learning organisations, continuously adapting management, organisation and skills to accommodate new technologies. They are also joined in networks, where interactive learning involving producers and users in experimentation and exchange of information is the driver of innovation (EIMS, 1994).

The knowledge-based economy places great importance on the diffusion and use of information and knowledge as well as its creation. The determinants of success of enterprises, and of national economies as a whole, is ever more reliant upon their effectiveness in gathering and utilising knowledge. Strategic know-how and competence are being developed interactively and shared within sub-groups and networks, where know-who is significant. The economy becomes a hierarchy of networks, driven by the acceleration in the rate of change and the rate of learning. What is created is a network society, where the opportunity and capability to get access 
to and join knowledge - and learning- intensive relations determines the socio-economic position of individuals and firms (David and Foray, 1995).

The science system is a crucial element in knowledge transmission, particularly the education and training of scientists and engineers. In the knowledge-based economy, learning becomes extremely important in determining the fate of individuals, firms and national economies. Human capabilities for learning new skills and applying them are key to absorbing and using new technologies. Properly-trained researchers and technicians are essential for producing and applying both scientific and technological knowledge. The science system, especially universities, is central to educating and training the research workforce for the knowledge-based economy. 


\section{Bibliography:}

1. Abramowitz, M. (1989), Thinking about Growth, Cambridge University Press, Cambridge

2. Baldwin, J., B. Diverty and J. Johnson (1995), "Success, Innovation, Technology and Human Resource Strategies - An Interactive System", paper presented at the Conference on "The Effects of Technology and Innovation on Firm Performance and Employment", Washington, DC, 1-2 May

3. Bartel, A. (1995), "Training, Wage Growth and Job Performance: Evidence from a Company Database”, Journal of Labor Economics, Vol. 13

4. David, P. and D. Foray (1995), “Accessing and Expanding the Science and Technology Knowledge Base”, STI Review, No. 16, OECD, Paris

5. Gibbons, M., C. Limoge, H. Nowotny, S. Schwartzman, P. Scott and M. Trow (1994), The New Production of Knowledge: The Dynamics of Science and Research in Contemporary Societies, Sage Publications, London

6. Lundvall, B. and B. Johnson (1994), "The Learning Economy”, Journal of Industry Studies, Vol. 1, No. 2

7. Smith, K. (1995), “Interactions in Knowledge Systems: Foundations, Policy Implications and Empirical Methods”, STI Review, No. 16, OECD, Paris 